\title{
Stanisław Chrobak (red.), Ksiqdz Bosko w wypowiedziach Papieży, cz. I, Wydawnictwo Salezjańskie, Warszawa 2014, ss. 267
}

DOI: http://dx.doi.org/10.12775/PCh.2014.035

Wychowanie nigdy nie było procesem łatwym, a we współczesnym świecie osiaganie założonych celów wychowawczych, opartych na właściwej hierarchii, promującej wartości uniwersalne, jest szczególnie skomplikowane. Nawet dorosłym trudno jest się odnaleźć w pełnym sprzeczności i chaosu świecie. Rewolucja informacyjna, zamiast uporządkować świat, uczyniła go jeszcze bardziej niezrozumiałym, zwłaszcza w sferze moralnej. Panujący pluralizm opinii, poglądów, przekonań, norm i wartości sprawia, że do młodych ludzi docierają niejednokrotnie sprzeczne lub niespójne treści, powodujące dezorientację niedojrzałych społecznie jednostek. Zasypywani informacjami nie są w stanie już ich porządkować i wartościować. Promowanie materialistycznej i hedonistycznej mentalności, gdzie życie tylko wtedy jest wartością, gdy oznacza zdrowie, młodość i piękno - ma zachęcić młodego człowieka do sięgania po to, co najlepsze, korzystania z tego, co dostępne. Kult plastiku, tymczasowości, kulturowe zwrócenie się w stronę zachodu i bezkrytyczne czerpanie z jego wzorców, apoteoza pieniądza i konsumpcji to rzeczywistość, w jakiej przyszło żyć dzisiejszej polskiej młodzieży. Podejście to rzadko pozwala na refleksję, na pytania, co jest dobre, a co złe; co słuszne, a co niesłuszne.

Młodzi ludzie są osobami dopiero rozwijającymi się, o nieukształtowanej jeszcze do końca psychice. Ich ubogie doświadczenie życiowe nie pozwala na samodzielny wybór właściwej drogi postępowania i wiodących w życiu wartości. Zdaniem psychologów, właśnie dzieciństwo i okres młodzieńczy jest okresem daleko bardziej niż dorosłość podatnym na powstawanie różnorodnych zaburzeń. Brak niezbędnych mechanizmów i umiejętności do radzenia sobie z sytuacjami trudnymi, opanowania zasadniczych technik adaptacyjnych, słabość fizyczna i psychiczna narażają dziecko na utrwalanie niekorzystnych nawyków. Ich globalne przeżywanie silnie utrwala skutki i znacznie utrudnia ich przezwyciężanie, zapoczątkowując proces rozległych deformacji osobowości człowieka dorosłego.

Upadek autorytetów instytucji, ich bezsilność wobec wyzwań współczesności nie pozwala na skuteczne realizowanie zadań wychowawczych w stosunku do młodych ludzi. Również rodzina często nie potrafi odpowiadać na potrzeby młodego człowieka - coraz powszechniejsza staje się psychiczna nieobecność dorosłych w świecie dzieci, obustronna hibernacja emocjonalna, 
załamanie się dialogu miedzy rodzicami a dziećmi. Rodzice boją się wkraczać w intymna, osobistą sferę życia młodego człowieka, a ukształtowani $\mathrm{w}$ innych niż obecne warunkach często nie są w stanie dostrzec zagrożenia, bo nie mieści się ono w ich percepcji. Wszystko to sprawia, że młodzi ludzie na własną rękę szukają drogowskazów, by znaleźć drogę w codziennym bezmiarze faktów, opinii i wydarzeń.

W tej sytuacji pojawia się pytanie - w jaki sposób projektować, planować i realizować proces wychowawczy? Jakimi regułami się kierować? Jak prowadzić młodych ludzi ku pozytywnemu odkrywaniu własnej tożsamości, uczyć ich wyboru dobra i wartości uniwersalnych w realizacji własnej koncepcji życia? Jak sprawić, aby dojrzewający człowiek stawał się coraz bardziej autentyczny? Jak, „wydobywać” z niego jego własny potencjał człowieczeństwa? Poszukując odpowiedzi na te pytania, współczesna pedagogika próbuje tworzyć nowe koncepcje wychowawcze, adekwatne do współczesnych warunków życiowych dzieci i młodzieży. Konstruowane są nowatorskie wizje metodyczne, wdrażane z wysiłkiem w praktykę pedagogiczną, nie zawsze przynoszące oczekiwane efekty.

Tymczasem niejednokrotnie okazuje się, że niektóre znane od lat systemy i koncepcje pedagogiczne, funkcjonujące w niezmienionej przez lata formie i podstawowej wizji, stanowić mogą odpowiedź na aktualne (w każdej epoce, również współczesnej) problemy wychowawcze i w sposób adekwatny umożliwiać realizację założonych w nich celów. Przykładem takiej koncepcji może stać się ponadczasowy system wychowawczy, stworzony przez św. Jana Bosko.

Wielu pedagogów o św. Janie Bosko mówi dziś jako o jednym z największych współczesnych wychowawców, twórcy skutecznego i niepowtarzalnego systemu wychowania, wiążącego się nie tyle z teorią, ile z praktyką wychowawczą, opartego na dialogu, miłości i kształtowaniu wyższych wartości. System ten jest od lat stosowany we wszystkich salezjańskich dziełach wychowawczych, również w szkołach, i przynosi nieprawdopodobne - nawet w trudnej wychowawczo współczesności - efekty, mogąc także stanowić wzór dla współczesnego wychowania rodzinnego.

Analiza wychowawczego trójmianu systemu prewencyjnego ukazuje głębię i pedagogiczną intuicję św. Jana Bosko, który przyjmując rozum, religię i miłość za filary swego systemu podkreśla wagę pełnego, integralnego wychowana człowieka. Sekret tej głębi polega na tym, iż św. Jan Bosko wychodził naprzeciw oczekiwaniom młodych ludzi, ich chęci życia, pragnienia akceptacji, miłości, radości i dobra. System prewencyjny w opinii wielu teoretyków i praktyków pedagogiki jest uznawany za system ponad- 
czasowy, ponieważ polega przede wszystkim na tworzeniu określonej relacji wychowawca-wychowanek. Obejmuje wszystkie najważniejsze płaszczyzny wychowania, nie zaniedbując tego, co w nim ludzkie, ani tego, co nadprzyrodzone. Mimo iż system ten jest trudny, stawiający wychowawcy szczególne wyzwania, zarówno w przestrzeni rozwoju osobistego, jak też metodyki pracy wychowawczej, służy on wzrastaniu młodego człowieka do pełni dojrzałości.

$\mathrm{Na}$ temat systemu wychowawczego św. Jana Bosko wypowiadało się wiele osób o różnym statusie zawodowym i naukowym. Po wielokroć analizowano go w różnych kontekstach społecznych, wychowawczych, socjalizacyjnych i resocjalizacyjnych, nawet rewalidacyjnych, w odniesieniu do osób w różnym wieku, o różnym poziomie rozwoju. Analizy tej dokonywali także kolejni papieże, odnosząc ten system do różnorodnych zjawisk i problemów wychowawczych i społecznych, aktualnych w czasach ich pontyfikatu.

Opracowanie, przedstawione w 2014 roku przez Stanisława Chrobaka, stanowi zbiór tekstów, dotyczących św. Jana Bosko i jego dzieła wychowawczego ze specyficznej perspektywy nauczania i dogmatów Kościoła katolickiego. Obejmuje on wypowiedzi czterech papieży z lat 1927-1978: Piusa XI, Piusa XII, Jana XXIII i Pawła VI. Redaktor pracy podjął się poważnego wyzwania - wyodrębnienia spośród ogromu papieskich dokumentów tych, które w całości lub choćby w części odnoszą się do wskazanego tematu. Wymagało to zapewne wielogodzinnego analizowania tekstów źródłowych, jak również głębokiej znajomości głównego problemu - gdyż niektóre z cytowanych fragmentów nie odnoszą się bezpośrednio do osoby Jana Bosko, jednak stanowią one cenne nawiązanie do jego systemu wychowawczego, umożliwiające głębsze zrozumienie jego specyfiki i zasadniczych założeń.

Zebrane wypowiedzi papieży ukazują św. Jana Bosko w różnych kontekstach - jako wielkiego świętego o wyjątkowych cnotach; przewodnika duchowego, wskazującego przez swoje życie i działalność drogę ku najwyższym wartościom; jedynego w swoim rodzaju sługę Kościoła, „który miał prawdziwą i skuteczną świadomość, że jest narzędziem Odkupienia" (Pius XI, s. 89); jako społecznika, człowieka wielkiej dobroczynnej pracy, wiernego swojemu posłannictwu. Przede wszystkim jednak charakteryzują go jako wielkiego wychowawcę, który w szczególny sposób potrafił dotrzeć do serc młodych ludzi, obudzić w nich ukryty potencjał i pobudzić do poszukiwania i realizowania dobra; który dzięki własnym cechom osobowościowym stworzył swoistą pedagogię, pełną radości życia, światła i ojcowskiego ciepła - dzięki intuicyjnie odczuwanej wychowawczej miłości, 
rozumnym wymaganiom i kierowaniu się chrześcijańskimi wartościami. Wychowawcę, który nie tylko stał się patronem wielu instytucji i sposobów działania ewangelizacyjnego, społecznego i pedagogicznego, ale też wzorem postępowania - miłości ludzi i Boga. W wypowiedziach papieży odnaleźć można głębokie przekonanie, że pedagogia św. Jana Bosko i stworzone przez niego dzieło wychowawcze mogą stanowić drogę skutecznych apostolskich i duszpasterskich działań wobec kolejnych rewolucji idei pedagogicznych i zagrożeń moralnych, jakie współczesny świat stawia przed młodymi ludźmi.

Zebrane przez redaktora opracowania wypowiedzi papieży świadczą więc o tym, że św. Jan Bosko był nie tylko przez teoretyków i praktyków wychowania, ale też przez głowy Kościoła katolickiego uznawany za wybitną i szczególną osobę, realizującą i promującą wychowanie integralne - ideę wspierania wychowanka do wzrastania w człowieczeństwie i pobudzania go do osobowego sposobu życia w kontekście całości relacji, w jakie jest uwikłana jego egzystencja - biologicznych, społecznych, psychicznych i duchowych (por. Paweł VI, s. 6).

Zawarta w tytule opracowania wskazówka - cz. I - sugeruje, że redaktor planuje kontynuowanie tematu w odniesieniu do kolejnych papieży. Z pewnością będzie to równie interesujący zbiór wypowiedzi, odnoszący specyfikę systemu wychowawczego św. Jana Bosko do coraz bardziej skomplikowanej rzeczywistości społecznej we współczesnych nam czasach. Czytelnik pierwszego tomu z pewnością sięgnie i po kolejną część tego opracowania, pobudzony pytaniem: jak w kontekście zachodzących przemian społecznych, politycznych i gospodarczych pod koniec XX i na początku XXI kolejni papieże definiowali znaczenie i aktualność tego systemu wobec pojawiających się nowych socjologicznych i pedagogicznych problemów? Czy system, stworzony ponad dwa wieki temu może zdaniem papieży stanowić antidotum na zagrożenia procesu wychowania we współczesnym świecie?

Lidia Marszałek*

* Dr hab. Lidia Marszałek, prof. Pedagogium, kieruje Zakładem Wychowania Przedszkolnego i Nauczania Początkowego w Instytucie Nauk Społecznych Wyższej Szkoły Nauk Społecznych Pedagogium w Warszawie. 